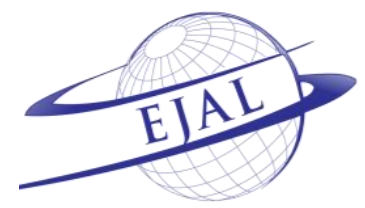

\title{
Variation sets in child-directed and child speech: A case study in Turkish
}

\author{
Vildan İnci-Kavak ${ }^{\mathrm{a} *}$ (D), Enes Kavak ${ }^{\mathrm{b}}$ \\ a Gaziantep University, School of Foreign Languages, Gaziantep, Turkey \\ ${ }^{b}$ Gaziantep University, Faculty of Arts and Sciences, Gaziantep, Turkey
}

Received 4 December 2019 | Received in revised form 17 June 2020 | Accepted 2 January 2021

\begin{abstract}
APA Citation:
İnci-Kavak, V., \& Kavak, E. (2021). Variation sets in child-directed and child speech: A case study in Turkish. Eurasian Journal of Applied Linguistics, 7(1), 1-23.
\end{abstract}

Doi: http://dx.doi.org/ 10.32601/ejal.911137

\begin{abstract}
This study analyses variation sets in a sample of child-directed speech (CDS) in Turkish in terms of their structure and effect on child speech. The term "variation set" was first introduced to describe the sequences of repetitions, in which the intention behind expressions stays the same throughout the whole conversation while the form shows constant variation. This occurs in various ways such as lexical substitution, rephrasing and so on. This study attempts to investigate the speech of a child aged 1;8 in various conversations with a Turkish native speaker parent who engages in daily activities with her son. As a longitudinal study, the data was collected through video recordings for a period of three months covering the child's developmental stages from the age $1 ; 8$ to $1 ; 10$. The videos were recorded by the mother on a regular basis during day-time activities in play, meal and leisure times each week. Initially, the recorded data was transcribed and variation sets were identified. Later, they were analysed by looking at their structure and functions in the speech. Finally, the findings were compared with each other (in three sets) for the changes in frequency, structure and functions between the ages of $1 ; 8$ to $1 ; 10$. The data provide ample evidence on how variation sets in CDS are modified for a successful interaction without a communication breakdown in line with the child's linguistic competence.
\end{abstract}

(C) 2021 EJAL \& the Authors. Published by Eurasian Journal of Applied Linguistics (EJAL). This is an open-access article distributed under the terms and conditions of the Creative Commons Attribution license (CC BY-NC-ND) (http://creativecommons.org/licenses/by-nc-nd/4.0/).

Keywords: CDS; variation sets; Turkish, first language acquisition; mother tongue

\section{Introduction}

The interaction between a child and his/her parents is a popular topic of research that has generated particular interest in the field of language acquisition. The role of child-directed speech (CDS) has mostly been ignored until recently and researchers' primary focus has been on children's early utterances as it is often thought that parents' speech has little or no direct impact on a child's language acquisition

\footnotetext{
* Corresponding author. Tel.: +0 3423172936

E-mail address: vildan_elt@hotmail.com

http://dx.doi.org/ 10.32601/ejal.911137
} 
(Innatist Theory, Chomsky, 1988). Nonetheless, the studies carried out after the 1990s established that there is a close relationship between the input by a parent and output by his/her child. In the studies carried out by Barrett, Harris, \& Chasin (1992); Ninio (1992) and Pine, Lieven \& Rowland (1997), it was confirmed that words used by parent and child show apparent similarities such as shared nouns and verbs.

CDS differs from an adult-directed speech in many ways. The length, speech rate, syntactic complexity and constant repetition (Broen, 1972) can be given as examples of divergence. Some other features are frequently-changing intonation, low lexical diversity, shorter and "here and now"-centered sentences (Gallaway \& Richards, 1994; Snow \& Ferguson, 1977). Thus, children who are exposed to this type of speech become familiar with the ambient language through the variations before they become capable of decoding the system of language directed to them.

As a distinctive feature of CDS, repetitions are frequently preferred in the interactions. They are called "variation sets" when sequences of repetitions follow each other in different forms but with the same interactional aim (Küntay \& Slobin, 1996; Clark, 2009, p. 37). The variation sets fulfil some essential functions such as attention-getting and holding for successful communication between a parent and child. In the previous studies, some additional functions of the variations sets have been shown as "phonetic segmentation" (Bard \& Anderson, 1983), being a "syntax predictor" (Hoff-Ginsberg, 1986; Hoff-Ginsberg, 1990; Waterfall, 2006) and a "social and attentional cue provider" (Frank, Bod \& Christiansen, 2012). All these provide a rich and broad context for a child to draw logical inferences and eventually comprehend utterances in a meaningful way.

Another study in 2008 (Onnis, Waterfall, \& Edelman, 2008) showed that adults who were exposed to variation sets in interactions were more successful in analysing sentence structures such as phrase segmentation and boundary detection. It claimed that variation sets help our brains work like a computer and "local mechanisms of alignment and comparison allow even memory-limited learners to discover structure that they would otherwise miss" (Onnis et al., 2008, p. 424). Variation sets let children become aware of the patterns and standardise them with a constant linguistic analysis (Gleitman, Newport, \& Gleitman, 1984).

\subsection{Variation sets in child-directed speech}

Parents, especially mothers, talk to their children even before they are born in some cultures and the way they talk differs from the adult speech in many ways (Fernald \& Mazzie, 1991; Jusczyk, Hirsh-Pasek, Kemler Nelson, Kennedy, Woodward, \& Piwoz, 1992; Lederer \& Kelly, 1991; Morgan, 1986). However, in some cultures such as Yucatec Mayan parents, children are directed no or very little speech (Shneidman \& Goldin-Meadow, 2012), but these children still manage to acquire language by overhearing it. Therefore, it can be assumed that "adult talk directed to children is important for early word learning, even in communities where much of children's early language input comes from overheard speech" (Shneidman \& Goldin-Meadow, 
2012, p. 659). Harris (1990) also claims that if children have a lack of CDS in their childhood, they may face problems with academic studies.

CDS is habitually kept simplified to make it ideal for the capacity of child (Matychuk, 2005). Prosodic features are also exaggerated by parents to make the language clear for the child (Fernald, 1989; Papousek \& Papousek, 1981). Parents do all these simplifications and adjustments in their speech directed to their child in a very gentle and natural way that they are not even aware of doing them (Fernald, 1976). The context and the "here and now" objects are generally the subject of interaction and all the content is open to adjustments. These are context-sensitive (Altınkamış, Kern, \& Sofu, 2014) and are not often used in another context (Papousek \& Papousek, 1987).

Repetition -partial or exact- is one of the most distinctive features of CDS. There have been notable studies having analysed how repetitions in CDS are shaped through the years (Broen, 1972; Snow, 1972; Kaye, 1980 \& Hoff-Ginsberg, 1986; 1990). In these studies, the repetitions were called the "clusters of sequential sentences" (Broen, 1972, p. 29, 43), which underlines that "the meaning remains constant" (Snow, 1972, p. 553). Küntay and Slobin (1996) coined the term "variation set" by referring to the sequential repetitions of various forms with the same intention. They also detailed it by pointing out that the central component is generally a verb. The verb and other components are subject to alternations such as "lexical substitution and rephrasing, addition and deletion of specific referential terms, and reordering of constituents" (Küntay \& Slobin, 2002, p. 6). They revealed that a rich variety of adjustments are needed not solely to repeat the message but to maintain the conversation. Briefly, variation sets appear to be more complex clusters of sentences than repetitions. If a new utterance does not have the above-mentioned qualities, it cannot be counted as part of an existing variation set.

\subsection{Social interactionist theory}

This study is supported by social interactionist theory, which advocates that the environment of a child is vital for language growth (Piper, 1998). Parents are also seen as an important constituent of the child's language learning process. The supporters of this theory believe that children are born with an innate predisposition to language learning. However, the social environment of the child is more crucial than this innate disposition (Piper, 1998). Several studies conducted on the topic concentrated on how CDS supports language acquisition (Gallaway \& Richards, 1994; Field, Woodson, Greenberg \& Cohen, 1982; Stern, Beebe, Jaffe \& Bennet, 1977). As an exponent of the theory, Piper (1998) states that "parents play an important role in matching the language input to the appropriate level of cognitive and language development of their children." (p. 168). Thus, caregivers have a vital role in the child's language acquisition. They make certain changes to appropriate their speech, but these alternations are not predetermined. These often occur in impromptu interactions. The parents try to communicate naturally with their child without being 
misunderstood. When misunderstanding arises, they maintain the communication with the child in different ways. Therefore, they adjust their language use to the linguistic and cognitive needs of their child instinctively. These adjustments are dependent on the abilities of the child and open to change through days and years, even from one episode of interaction to another (Snow, 1995). The parent talking to the child makes such alterations to fine-tune and flatten the differences. According to Snow (1995), the child-directed speech

differs from speech among peers on a variety of dimensions. It is syntactically simpler, more limited in vocabulary and in prepositional complexity, more correct, and more fluent... In other ways, though, CDS is still quite complex; it displays full range of conventional indirectness, for example, without the simplification of form-function one might expect (Shatz, 1978). While in general, CDS is constrained to the here-and-now and related to the child's focus of attention or ongoing activity, a high proportion of at least some mothers' CDS redirects children's attention and activity, introduces onpresent referents, and in other ways seems to complicate the task of learning language (p. 180).

Social constructivism claims that language is not only acquired with the help of biological contributions but also with the social and cultural environment. The immediate environment of a child is highly important because it builds the context of interaction (the here-and-now). This theory rejects the extreme poles of nativism and behaviourism. Dickinson and McCabe (1991) state that "whereas behavioural and linguistic approaches to language acquisition are on opposite extremes of the empiricism-nativism pole, social interactionism is an approach that acknowledges biological contributions to the language acquisition process but emphasises also the way that language is acquired socially." (p. 10). They explain how CDS supports the child's intellectual achievement as follows:

- The language produced by the child is always expanded on with semantically contingent speech (for ex: Child: apple; Parent: It's a nice, juicy apple, isn't it?), which facilitates children's language acquisition (Clark-Stewart, 1973; Cross, 1976; Snow, 1984; Wells, 1980).

- Children quickly acquire content vocabulary that applies to objects which get their attention, not the grammatical words such as indefinite articles "a/an" even if they are highly frequent in CDS.

- Children may utilise imitation selectively as a technique for various reasons such as keeping the conversation going, practicing unfamiliar forms of language and learning new forms.

- Children and parents negotiate meaning mutually and it can often continue until they succeed in this meaning-making process. (1991)

These statements particularly highlight the interactive nature of language between a parent and child. At this point, behaviourist or nativist theories to L1 acquisition can no longer be deemed valid. The L1 acquisition is more convoluted than stimulus- 
response conditioning as the behaviourist theory proposes and it cannot be explained by the here-and-now nature of parent-child talk as the nativist language theory suggest. Briefly, CDS aids a child to explore and eventually develop skills in the first language. CDS produced by parents, however, represents a linguistic system that addresses many different functions in parent-child interactions.

\subsection{Related studies}

Küntay and Slobin (1996) recorded a Turkish mother and her child for seven months. The child was aged 1;8 at the beginning of the study, which continued until the child reached the age of $2 ; 3$. The study showed that $21 \%$ of the utterances could be placed in variation sets. All the sets identified were formed around a verb that the child had recently acquired. They continued to examine the variation sets with new participants in another study in 2002. They questioned whether the data would provide similar results, by giving a special focus on the functions of the sets in the speech. In the follow-up study, they chose a 1;3 year-old child and they analysed how the functions had changed until the child turned 2;0 (Küntay \& Slobin, 2002).

The aforementioned studies were taken by studies that followed them in various languages as reference works. A study on the same topic was carried out by Waterfall (2006). She collected data from 12 mothers and their children who were aged between $1 ; 2$ and 2;6. She redefined the term "variation set" as the "sequences of utterances with similar or related meanings". She extended the study beyond what Küntay and Slobin $(1996,2002)$ set out, confirming that the central element of a variation set is not only a verb, but can be a noun. In other words, the noun or verb may repeat in all the lines of variation sets in potentially diverse forms. Waterfall asserted that the use of variation sets declines as the child grows up (from $17 \%$ at $1 ; 2$, to $12 \%$ at $2 ; 6$ ).

An alternative term for the sets was offered by Brodsky, Waterfall and Edelman (2007). They focused on the lexical overlap of one element in various lines of interaction and called this central component a "non-stop listed word" (2007). In another study, Onnis et al. (2008) used an automated system and found that there is a higher percentage of variation sets than it was in Waterfall's study (2006). Also, in a recent study, Che, Brooks, Alarcon, Yannaco, Francis and Donnelly (2018) investigated the relationship between overlap in content and language development by using CHILDES data and found out that the repetitions have a positive role in child language development by providing the "here and now" content that is immediately available or relevant to what the child has in mind.

\subsection{Variation sets in Turkish}

As an Altaic language, Turkish has two significant features: the first one is that it has a rich morphological system and the other is that it allows ellipsis and alternations in the word order. Speakers can omit subject or object in Turkish and the verbs are typically positioned at the end of the sentences (Göksel \& Kerslake, 2005; Slobin, 1982). Due to its highly agglutinating nature, Turkish exhibits not only 
case but also possession and plurality. Additionally, verbs can mark tense, modality, negation, subject agreement and voice morphemes.

The reference studies on the Turkish variation sets were originally carried out by Küntay and Slobin $(1995,1996,2001)$ with Turkish speakers and studies in other languages have followed them. Pursuing similar goals, but with a specific focus on child-directed and child speech patterns, our study attempts to contribute to the field of language acquisition by analysing the verbal interaction of native Turkish participants. As the Turkish language has a rich morphological system, it permits speakers to produce numerous variations by reordering and ellipses. In other words, Turkish provides distinct possibilities for speakers to vary and enrich their speech. Thus, it is not surprising for researchers to come across diverse variation sets in Turkish CDS. The examples below have been borrowed from Küntay and Slobin's 1996 study:

Example 1:

ban-a oda-n-dan bi tane

pro.1s-dat room-poss.2s-abl indef1

bebek getirebilirmisin?

Doll bring-mod-yn-2s

'Can you bring me a doll from your room?'

Getir

bring

'Bring.'

Getir bebeğ-in-i.

bring doll-poss.2s-acc

'Bring your doll.'

(Mine, 1;7)

In this example, the mother asks her daughter to bring a doll from her room. First, she divides the full sentence into two parts. In the second attempt, the mother removes all the components of the sentence to such an extent that there remains an action verb only. In the last attempt, only the verb and object are uttered. The verb "bring" is repeated in all lines, which is an example of the "non-stop listed word" in Brodsky et al.'s terms (2007). The noun or the object of the sentence "doll" follows the verb and is used in three lines. The morphological variation of the words can be observed in the right column.

Example 2:

git dök-elim artık bu su-yu

go pour-opt.1s just this water-acc

'Let's just go and pour this water.'

Git

Go

'go'

nere-ye dök?

Where-dat pour

'Where (should we/you) pour it?'

banyo-ya götür

bath-dat take

'Take (it) to the bath(tub)?' 
banyo-ya götür dök

'Take (it) to the bath(tub) (and) pour.'

Kalk banyo-ya götür dök su-yu bath-dat take pour

get.up bath-dat take pour water-acc

'Get up and take (it) to the bath(tub) (and) pour the water.'

(Gül, 1;9)

Example 2 is an extract from the same study. For a 21-month-old child, comprehending an activity including various steps can be very challenging. Aside from its physical complexity, it would take a lot of effort for the child to be able to fulfil the task, so the speech is simplified to fit into the child's level of comprehension in the form of short instructions such as "go", "take it to the bathtub" and "pour". In other words, speakers make lexical differentiation by utilising agglutinated morphology of the Turkish language in variation sets (Küntay \& Slobin, 2001).

\subsection{Functions of variation sets}

In the previous example, the communicative function of variation sets is to grab and keep the child's attention, so s/he can carry out the task the parent asks or can produce an utterance the parent expects. In Küntay and Slobin's study, three types of interactional functions are identified (2002). However, Schiffrin (1987) stresses that all these functions can be available in variation sets simultaneously. These are

- control-oriented variation sets

- ideational variation sets

- information-querying variation sets

Control-oriented variation sets necessitate the child to perform an action that is controlled by the parent (Ervin-Tripp, 1989).

Example 3:

hayır ayakkabı el-len-me-z

no shoe touch-pas-neg-aor

'no, shoe(s) (is/are) not touched'

(Küntay \& Slobin, 2002, p. 5)

Ideational variation sets function as sharing information between the parent and child.

Example 4:

Deniz bak bi(r) tane gemi resm-i yap-ıyor-um ben. Deniz look indef boat picture-poss do-prog-1sg I

'Deniz, look, I am doing a drawing of a boat'

gemi:!

Boat

'Boa:t'

(Küntay \& Slobin, 2002, p. 5)

Information-querying variation sets suppose that the child will answer a question. The parent asks questions as s/he looks for an answer on the topic. 
Example 5:

ne var-miş bur(a)-da?

what exist-evid here-loc

'What is in here?'

var mi bi(r)şeyler?

exist yn something

'Is there anything?'

(Küntay \& Slobin, 2002, p. 5)

\subsection{Research questions}

CDS is about the negotiation between a parent and child although their speech may not always end with a positive response from the child. As the child develops linguistically, physically and mentally, s/he attempts to produce more adult-like speech and takes more turns, so the negotiation between the parent and child becomes more balanced and bilateral. Therefore, this study aims to analyse the nature, complexity and functions of variation sets in CDS in the light of the previous research. The noun-verb symmetry and morphological diversity in variation sets will also be given particular interest. To do so, it presents the result of a case study that meticulously examines both the utterances of a child in early language development and the language directed at him. The questions below will be guiding the research:

1. What is the ratio between the parent's and the child's use of verb in CDS and CS?

2. Is there a(n) (a)symmetrical relationship between them?

3. What is the ratio between the parent's and child's use of nouns in CDS and CS?

4. Is there a(n) (a)symmetrical relationship between them?

5 . What is the parent's pragmatic intention in the child-directed variation sets?

6 . Are there any changes in the nature of variation sets as the child gets older?

\section{Methodology}

The collected data involved the records of interactions between caregivers and a toddler. The recordings were regularly taken in the family's flat. The adults who participated in the data were typically his mother, father, grandmother and some family friends. They were all native speakers of Turkish. The mother recorded the child for an hour every week. The family was also visited by the researcher to take notes on the nature and conditions of interactions. The family was asked to carry on their daily lives during the recordings. There was no structured activity planned in advance. The data and its collection process, which took around 12 weeks, were kept as natural and true-to-life as possible.

\subsection{Participants}

The study examines a child from the ages of $1 ; 8$ to $1 ; 10$ during his daily activities such as playtimes, dinner and reading times. The data were collected from a Turkish- 
speaking family. The interactions between the child and parent were video recorded, which allowed us to analyse paralinguistic features as well. The parents are both highly educated; the father works as an assistant professor at a Turkish public university and the mother is a BA graduate of two separate departments: Translation Studies (French) and English Language Teaching and she teaches English at a college in Turkey. The family loves travelling and has been to various countries. Even the child has visited countries such as England and Macedonia starting from a very early age. As can be understood from their education and lifestyle, the family members have multilingual backgrounds. The child has been exposed to English through casual dialogues, games and videos. The family appears to provide the child with a rich linguistic and multicultural atmosphere.

\subsection{Procedure}

The data were collected longitudinally and were expected to provide exhaustive material on the recurrent lexis or structures in the interaction. It consisted of transcriptions of CDS samples. The data were transcribed and coded by trained researchers. Utterances, exclamations and sentence fragments that were unintelligible and would not contribute to the study as CDS were discarded in the coding.

\subsubsection{Coding}

Transcripts coded for lexical and pragmatic criteria are explained below:

- All varieties of nouns such as common, proper names and kinship terms were counted in parents' and child's speech. However, vocative nouns were discarded.

- All main verbs were counted in parents' and child's speech. However, only action verbs expressing an action, a process or a sensation were counted and state verbs were discarded. The study had a context-sensitive approach towards the data as exemplified below:

$$
\begin{array}{ll}
\text { (eve) gid-iyor-um } & \text { go-Present Cont. Tense- 1PS } \\
\text { (hoşuma) gid-iyor } & \text { go-Present Cont. Tense- 3PS }
\end{array}
$$

While the verb "go" is used as an action verb in the first one, it is used as a state verb in the second example. Although the first verb was counted for the analysis, the second was not considered.

- No auxiliary or modal verb and no form of the copula "araba var" (there is a car) were counted.

- Terms or exclamations for grabbing attention such as "bak" (look!) were not counted as they do not direct the child to action.

- Repetitions were counted only once when they met the above criteria.

- Nouns and verbs were analysed for two main categories considering the reference studies in the field (Altınkamış, Kern, Sofu, 2014; Choi, 2000; Kim et al., 2000; Ogura et al., 2006): object-oriented and action-oriented utterances. 
- The word was labelled as "naming-oriented" when it elicited an object from the child, an object label directly/indirectly, encouraging the child to focus on an object/an entity. It was labelled "activity-oriented" when it encouraged the child to focus on action or state suggesting some type of action.

\subsubsection{Reliability}

A brief face-to-face meeting was arranged to explain the aims and the stages of the study after taking the participants' consent for the research. The family was ensured that the information on them and their child would be kept confidential and anonymous (Cohen, Manion \& Morrison, 2011). The data from the recordings were first transcribed and then analysed to be coded. Coding continued during and after the data collection period. However, as Hatch (2002) states "codes should not be defined as rigid regularities with sharp boundaries; they can also cover varying forms" (p.155). In other words, the codes are not completely permanent categories; rather, they are open to changes until data analysis has been completed. Saldana (2015) states that coding is an exploratory problem-solving technique and not simply about labelling some cases or examples; it eventually draws connections between the samples. The cyclical nature of the process should be highlighted since an ongoing analysis "leads you from the data to the idea, and from the idea to all the data pertaining to that idea" (Richards \& Morse, 2007, p. 137). Also, Bazeley (2007) states that making connections with a paper-and-pencil method is more researcher-friendly than other methods. Using a traditional method gives the researcher more control over the study and more physical ownership. Considering the small-scale of the current research, it was more practical to make a hard copy of the transcription, which was coded manually in this study.

Both the codes and transcription were checked by three $\mathrm{PhD}$ holders in the field of English Language Teaching who are native speakers of Turkish. When there were differences between the codes, they were resolved by the researchers in a discussion session. After reaching a consensus among the research team members, the transcriptions were emailed to the family for confirmation. Member- checking and peer-briefing (Creswell, 2012; Merriam, 1998) are techniques that were used to improve the trustworthiness and credibility of this study (Creswell, 2012; Janesick, 2004; Spillett, 2003; Spall, 1998; Lincoln \& Guba, 1985).

Table 1. Cohen Kappa's degree of agreement

\begin{tabular}{lllll}
\hline $\begin{array}{l}\text { Agreement Between } \\
\text { Raters }\end{array}$ & Percent & Value of Kappa & $\begin{array}{l}\text { Degree of } \\
\text { Agreement }\end{array}$ & Action Taken \\
\hline $3 / 3$ & $66,6 \%$ & $1.00-0.81$ & Perfect agreement & Include \\
$2 / 3$ & $24,6 \%$ & $0.80-0.61$ & Moderate agreement & Include \\
$1 / 3$ & $6,6 \%$ & $0.40-0.21$ & Fair agreement & Consensus needed \\
$0 / 3$ & $2,2 \%$ & $0.20-0.00$ & Poor agreement & Discard \\
\hline
\end{tabular}

After each rater coded data individually and ranked it separately by evaluating their functions in the interaction (noun, verb, discourse marker, variety set, etc). The raters were not given any predetermined codes in order not to interfere with their 
assessment. Crosschecks were carried out to increase the inter-coder reliability with Cohen Kappa's degree of agreement (Landis \& Koch, 1977). Table 1 illustrates the results, interpretation of the agreement as well as the action taken in this analysis. In practice, if more than half of the raters ( 2 or 3 out of 3 in this case) respond the same way, the decision was accepted final and included in the study. To illustrate, if rater 1 voted for verb use in a chosen sample, but rater 2 for a discourse marker, and finally, rater 3 suggested that it was a verb, the verb would be selected. Cohen Kappa's degree of agreement thus helped increase the reliability of the study.

\section{Findings and Discussion}

\subsection{Data analysis}

For a systematic and in-depth analysis, the data were divided into three sets based on the age of the child. To provide a better picture, a general look at the child's linguistic production is given in Table 2 . It reveals that the child could produce only $33 \%$ of total utterances when the study began. In a month, he had a slight rise by $3 \%$, from $33 \%$ to $36 \%$. Eventually, he showed a significant increase when he spoke $43 \%$ at the age of only $1 ; 10$.

Table 2. The percentage of child utterance

\begin{tabular}{lllll}
\hline Sets & Age & Total Utterance & Child Utterance & Percent \\
\hline Set 1 & $1 ; 8$ & 1140 & 381 & $33 \%$ \\
Set 2 & $1 ; 9$ & 1350 & 494 & $36 \%$ \\
Set 3 & $1 ; 10$ & 1574 & 676 & $43 \%$ \\
\hline
\end{tabular}

\subsection{Verb use}

Table 3 reveals the amount of verb use by the child. In Set 1, he produces $16 \%$ only whereas, in the second set, there is only a slight change up to $19 \%$. In the last slot, a clear development by $44 \%$ is observed in the use of verbs.

Table 3. The percentage of verb use by the child

\begin{tabular}{lllll}
\hline Sets & Slot & Child Total Utterance & Child Verb Use & Percent \\
\hline Set 1 & $1 ; 8$ & 381 & 56 & $16 \%$ \\
Set 2 & $1 ; 9$ & 494 & 96 & $19 \%$ \\
Set 3 & $1 ; 10$ & 676 & 295 & $44 \%$ \\
\hline
\end{tabular}

Table 4 shows the percentage of parent's verb use in three slots. In the first and second slots, she uses nearly the same amount of verbs and there is only a slight difference between the two of the sets. These differences result from various contexts such as book reading or toy playing. In the last set, there is a modest rise in the use of verb by the parent. As Table 3 shows, the child's verb use also increases by $7 \%$. This can be the reason why the parent increases the verb use in her/his speech. As the 
child mentally and linguistically develops, the parent expands the variety of verbs by adapting her/his speech to the cognitive capacity of the child.

Table 4. The percentage of verb use by the parent

\begin{tabular}{lllll}
\hline Sets & Age & Parent Total Utterance & Parent Verb Use & Percent \\
\hline Set 1 & $1 ; 8$ & 759 & 412 & $54 \%$ \\
Set 2 & $1 ; 9$ & 856 & 483 & $56 \%$ \\
Set 3 & $1 ; 10$ & 898 & 575 & $64 \%$ \\
\hline
\end{tabular}

Table 5 shows the comparison of the parent's and child's verb use. While the first lines of each set in the table show the parent's verb use, the second lines represent the child's verb production. As can be seen from the table, there is a symmetry between the ratio of rise in verb use by the parent and child. There is a slight but steady increase in the first two slots, but the difference contracts as the child linguistically improves. In the last one, the gap between parent's and child's verb use narrows down further.

Table 5. The comparison of the parent and child verb use

\begin{tabular}{lllll}
\hline Sets & Age & Total Utterance & Verb Use & Percent \\
\hline Set 1 & $1 ; 8$ & 759 & 412 & $54 \%$ \\
& & 381 & 56 & $16 \%$ \\
Set 2 & $1 ; 9$ & 856 & 483 & $56 \%$ \\
& & 494 & 96 & $19 \%$ \\
Set 3 & $1 ; 10$ & 898 & 575 & $64 \%$ \\
& & 676 & 295 & $44 \%$ \\
\hline
\end{tabular}

\subsection{Noun use}

Table 6 reveals the amount of noun uses by the child in three slots. Interestingly, there is no drop or rise in any of the slots in terms of noun use. The ratio of the use remains the same no matter what the child and parent do in different contexts. No rise is thus observed in noun use in opposition to verb use.

Table 6 . The percentage of noun use by the child

\begin{tabular}{lllll}
\hline Sets & Slot & Child Total Utterance & Child Noun Use & Percent \\
\hline Set 1 & $1 ; 8$ & 381 & 79 & $20 \%$ \\
Set 2 & $1 ; 9$ & 494 & 99 & $20 \%$ \\
Set 3 & $1 ; 10$ & 676 & 137 & $20 \%$ \\
\hline
\end{tabular}

The percentage of the parent's noun use between the ages of $1 ; 8$ and 1;10 can be found in Table 7. Whereas the parent's noun use is steady, there is a slight rise between the first and second slots.

Table 7: The percentage of noun use by the parent 


\begin{tabular}{lllll}
\hline Sets & Age & Parent Total Utterance & Parent Noun Use & Percent \\
\hline Set 1 & $1 ; 8$ & 759 & 226 & $30 \%$ \\
Set 2 & $1 ; 9$ & 856 & 271 & $32 \%$ \\
Set 3 & $1 ; 10$ & 898 & 291 & $32 \%$ \\
\hline
\end{tabular}

To be able to see all the details about the parent's and the child's noun use and draw a meaningful comparison, Table 8 has been studied. When we look at the gap between parent's and the child's noun use, the gap between the number of nouns they use in their speech remains the same; it does not open up or narrows down during the successive months. The reason for this can be that the verb frequency and distribution are wider than noun inflections, which is parallel to Sofu and Türkay's study (2004). In other words, there is more and varied use of a verb than a common noun (Please see the sample noun and verb variation sets in the data analysis section.).

Table 8: The comparison of parent and child noun use

\begin{tabular}{lllll}
\hline Sets & Age & Total Utterance & Noun Use & Percent \\
\hline Set 1 & $1 ; 8$ & 759 & 226 & $30 \%$ \\
& & 381 & 79 & $20 \%$ \\
Set 2 & $1 ; 9$ & 856 & 271 & $32 \%$ \\
& & 494 & 99 & $20 \%$ \\
Set 3 & $1 ; 10$ & 898 & 291 & $32 \%$ \\
& & 676 & 137 & $20 \%$ \\
\hline
\end{tabular}

\subsection{Samples of variation sets in Turkish CDS}

Set 1

Extract $1(1 ; 8)$

$1 \quad$ MOT: arabayı da yıkicak misın? will you wash the car?

2 MOT: arabayı the car

$3 \quad$ MOT: arabada mı cıp cıp yapcak? it will get washed too?

4 CHI: evet yes

5 MOT: huh? huh?

$6 \quad$ MOT: sen cıp cıp yapmayı seviyor musun? do you like getting washed?

7 CHI: evet yes

8 MOT: çok mu seviyorsun? do you like it a lot?

9 CHI: evet yes

Extract 1 shows us a sample from the time when the child was only 20 months old. As a representative of the information-querying variation set, the mother tries to receive a reply from the child about her question in the first 3 lines. As the child is familiar with the verb yıkamak and the object araba (the car), she expects her child to understand the questions, which, however, causes a breakdown in the communication 
as she points to the objects she means without using the verb. Unfortunately, the child does not give a response and she uses an onomatopoeic phrase cıp cıp yapmakwhich corresponds to "swish swash" in English-instead of yıkamak (to wash) in line 6 because onomatopoeic sounds are often easier for a child to comprehend. In line 7, the mother gets a short answer and keeps the conversation on the same topic. This extract is an example of how a parent simplifies or modifies her/his speech to adapt the level of conversation to that of the child's linguistic abilities until they can achieve effective communication.

Extract $2(1 ; 8)$

1 MOT: ne verdin kuşa?

2 MOT: hum?

3 MOT: ne verdin kuşa?

4 MOT: hum?

$5 \quad$ MOT: kuşa ne verdin oğlum?

6 MOT: simit verdin mi?

$7 \quad$ CHI: evet

$8 \quad$ MOT: huh ne verdin?

$9 \quad$ CHI:14imit simiit what did you give to the bird?

hum?

what did you give to the bird?

hum?

what did you give to the bird, son?

did you give "simit" (A type of

Turkish bagel)

yes

what did you give?

imit"simiit"

Extract 2 was also taken from the same set as the previous one. However, here we witness different strategies in comparison to the previous one. It functions as an information-querying variation set because the mother wants her child to name the food that he has given to a bird. The first six lines are produced by the mother with the same intention, but she is not successful until she names the food simit herself in line 6 . In lines 1 and 3 , we can observe exact repetition that is aimed to get the attention of the child. It is also supported with discourse markers "hum?" in lines 2 and 4 . Until here, the mother thinks that she can get a response only by getting the attention of the child because she does not apply any morphological change to the utterance. In the 5th line, she changes the word order from "what gave the bird" (OVC) to "the bird what gave son" (COV). In line 6, the mother gives a clue by naming the object she has been asking the child to name but in the interrogative form. Finally, she gets a response, which, yet, does not satisfy her, so in line 8 she asks the child to repeat the word "simit" to practice it and move to another topic. The mother does not consent conversation to flow freely and directs it to the way she desires.

\section{Set 2}

Extract $3(1 ; 9)$

1 MOT: ne yiyorsun?

what are you eating?

2 CHI: (he points to his mouth) 


$\begin{array}{lll}3 & \text { MOT: ney o? } & \text { what's that? } \\ 4 & \text { MOT: mandalina mı? } & \text { (Is it) a tangerine? } \\ 5 & \text { MOT: yoksa mandalinanın kabuğu mu? } & \text { or is it tangerine skin? } \\ 6 & \text { CHI: (he nods) } & \\ 7 & \text { MOT: kabuk mu yiyorsun? } & \text { are you eating the skin (of it)? } \\ 8 & \text { CHI: } \text { evet } & \text { yes } \\ 9 & \text { MOT: ama kabuk yenmiyor } & \text { but the skin is not edible } \\ 10 & \text { MOT: güzel mi tadı? } & \text { does it taste nice? } \\ 11 & \text { CHI: } \text { evet } & \text { yes } \\ 12 & \text { MOT: humm } & \text { humm } \\ 13 & \text { MOT: ben de mi yesem acaba? } & \text { shall I eat it too? } \\ 14 & \text { CHI: huh } & \text { huh } \\ 15 & \text { MOT: ben de yemelimiyim ki? } & \text { should I eat it too? } \\ 16 & \text { CHI: huh } & \text { huh } \\ 17 & \text { MOT: ben de yiyim mi? } & \text { shall I eat it? } \\ 18 & \text { MOT: } \text { mandalina kabuğu? } & \text { the skin? } \\ 19 & \text { CHI: } \text { evet } & \text { yes }\end{array}$

This extract is taken from set 2 in which the child reaches the age of $1 ; 9$. The set functions as information-querying in the first half (lines 1-9), but then continues as a control-oriented variation set (lines 9-19). This extract clearly demonstrates that it is hard to categorise the functions of variation sets in the data as they continuously overlap. In this data set, the child eats the skin of a tangerine and the mother warns him not to do so. In the first line, the mother asks what he is eating. Instead of naming the fruit, the child opens his mouth and shows his mother what he is eating. The mother replaces her question with a more familiar one "what's that?" as the answer would be the same for the previous question, too. In line 4, she names the fruit, but as it is not what he is eating, it does not get any responses from the child. Until the mother provides the lexis he needs, he does not respond positively. Once the mother provides him with the word mandalina kabuğu (tangerine skin), the child responds by nodding. In the rest of the lines, the mother keeps asking similar questions in various morphological forms with the same intention. The extract presents a good example of a variation set on the verb yemek (to eat).

$\begin{array}{lll}\text { Yi-yor-sun } & \text { you eat } & \text { Eat PROG 2SG } \\ \text { Ye-n-mi-yor } & \text { not eaten } & \text { Eat PASS NEG PROG } \\ \text { Ye-se-m } & \text { if I eat } & \text { Eat COND 1SG }\end{array}$




$\begin{array}{lll}\text { Ye-meli-mi-yim } & \text { should I eat } & \text { Eat NEC QUES 1SG } \\ \text { Yi-yim mi } & \text { shall I eat } & \text { Eat SUBJ 1SG QUES }\end{array}$

Extract $4(1 ; 9)$

$1 \quad$ CHI: çorapını (çorabımı)

my socks

2 MOT: çorabını

your socks

3 MOT: çorabına noldu?

what happened to your socks?

$4 \quad$ MOT: çorabında mı çıktı?

are your socks put off?

$5 \quad$ MOT: çorabınla mı durmak istiyorsun?

do you want to stay with your socks on?

$6 \quad \mathrm{CHI}$ : evet

yes

Extract 4 features a representative sample of a noun variation set in CDS. The child has taken off his socks and the mother tries to find out why he has done so In line 1, the child uses a keyword that is not clear for the mother. We understand from the video that he points to his own socks by saying çorabını (your socks) instead of çorabımı (my socks). In the following lines, the mother asks various questions by putting the lexis çorap (the sock) in the centre of them. Each time the mother uses çorap (the sock), she produces it in a new morphological form with different cases and suffixes. Even in this very short extract, the word çorap has been used five times, which clearly allows the child varied input for future uses.

$\begin{array}{lll}\text { Çorab-ım-1 } & \text { my socks } & \text { SOCK POSS 1SG ACC } \\ \text { Çorab-ın-1 } & \text { your socks } & \text { SOCK POSS 2SG ACC } \\ \text { Çorab-ın-a } & \text { to your socks } & \text { SOCK POSS 2SG DAT } \\ \text { Çorab-ın-da } & \text { in your socks } & \text { SOCK POSS 2SG LOC } \\ \text { Çorab-ın-la } & \text { with your socks } & \text { SOCK POSS 2SG INS }\end{array}$

Set 3

Extract $5(1 ; 10)$

1 MOT: ama biz oraya oturmuyoruz di mi? but we don't sit there, do we?

2 CHI: Huh? huh?

$3 \quad$ MOT: biz oraya oturuyor muyuz oglum? do we sit there, son?

4 CHI: evet yes

$5 \quad$ MOT: hayır oturmuyoruz no we don't sit

6 MOT: sadece sen oturuyorsun only you sit

7 CHI: Huh? huh?

8 MOT: sadece sen oturuyorsun oraya only you sit there 
$9 \quad$ CHI: Huh?

10 CHI: anne?

11 MOT: anne oturmuyor

12 CHI: sen neden oturuyorsun oraya?

13 CHI: buna (otur) (points to the TV unit)

14 MOT: neden?

15 CHI: masaya anne

16 MOT: biliyorum o masa

17 MOT: ama koltuğa oturman gerekiyo biliyo musun?

17 CHI: (no response)

18 MOT: Huh?

19 MOT: koltuğa oturmak ister misin?

20 CHI: Huh?

21 MOT: Huh?

22 CHI: buna da?

23 MOT: orası koltuk değil

24 MOT: orası masa

25 MOT: biz nereye oturuyoruz?

26 CHI: buna (pointing the table)

27 MOT: $c \imath k$ (a vocal negative gesture)

28 MOT: hayır biz

29 CHI: $a h h h h$ (points to his leg)

30 CHI: anne?

31 MOT: anne baba nereye oturuyor?

32 MOT: anneanne

33 MOT: nereye oturuyoruz biz? huh?

mummy?

mummy don't sit

why do you sit there?

(sit) here

why?

on the table mummy

I know it is a table

but do you know you should sit on the sofa

huh?

do you want to sit on the sofa?

huh?

huh?

here too?

that's not a sofa

that's a table

where do we sit?

here

no

no we

ahhhh

mummy?

where do mommy and daddy sit?

granny?

where do we sit?

34 CHI: buna (he points to a table and chairs)here

35 MOT: buna Ney? here what?

36 CHI: (he points to his nose)

37 MOT: burna değil (mother laughs) (we do) not (sit) on your nose 
$38 \quad$ MOT: nereye oturuyoruz biz oğlum? where do we sit, son?

39 MOT: koltuga mı oturuyoruz biz? do we sit on the sofa?

40 MOT: koltuk Dimi? on the sofa, right?

41 MOT: bak burası koltuk look, here is a sofa

42 MOT: eveet yes

43 CHI: bu? (points to the table) this?

44 MOT: o masa that's a table

45 MOT: ona oturulmuyor it is not for sitting

Extract 5 is taken from the last set in which the child is 22 months old. The child sits on the TV unit in the video and the mother tries to persuade him to sit on the sofa. As the child insists on his decision, the statements directed to him significantly vary and the mother uses various forms of the verb "to sit". As stated in the studies such as Sofu and Türkay (2004), and Tardif, Shatz and Naigles (1997), the Turkish verb inflection system is wider than nouns. The richness of verb inflections in Turkish is clearly reflected in this extract. The variation set for oturmak (to sit) is continuously varied in a morphological system by the mother as in the example:

Otur-mu-yor-uz

Otur-uyor - mu-yuz

Otur-uyor-sun

Otur-mu-yor

Otur

Otur-man gerek-iyor

Otur-uyor

Otur-uyor-uz

Otur-ul-mu-yor we aren't sitting

are we sitting?

you are sitting

$\mathrm{s} / \mathrm{he}$ is not sitting

sit (down)

you should sit

$\mathrm{s} / \mathrm{he}$ is sitting

we are sitting

it is not being sat
SIT NEG PROG 1PL

SIT PROG QUES 1PL

SIT PROG 2SG

SIT NEG PROG 3SG

SIT 2SG

SIT SUFF NEED PROG

SIT PROG 3SG

SIT PROG 1PL

SIT PASSIVE NEG PROG

\subsection{Variation sets in $C S$}

Extract $6(1 ; 8)$

1 CHI: anne çal (anne çalıştır)(in the car)

mummy, start (the car)

2 CHI: anne çal

mummy, start

$3 \quad \mathrm{CHI}: b a k b u$ (pointing the car key)

look, this

$4 \quad$ CHI: anne çal o

mummy, start that

$5 \quad$ MOT: humm anahtar istiyorsuun

humm, you want the key

This is a sample extract to show how the child uses variation sets for the same functions mentioned in the previous section (Please see 2.4.). This sample represents 
a control-oriented variation set that has been found in the child speech, not in the child-directed. The mother and child sit in the car and the child constantly wants his mother to start the car. He cannot pronounce the verb çalıştırmak (to start) properly, so he uses the exact repetition in variations as to stress and intonation. In the third line, he shows his mother what he needs to use to start (the car key). In the next line, he gives the car key to his mother and combines what he has just said in the previous lines. After this line, the message is conveyed and the mother understands what her son wants her to do. In other words, successful communication is accomplished with the help of variation sets by child speech. This extract proves that even at the very early ages such as 20 months, a child can use variation sets meaningfully and strategically. The way he uses them can alter while his linguistic collection expands. Therefore, he strategically produces more morphologically rich and intricate sentences. At this level, he enriches his language by using prosodic features, simplification, pointing and grading.

\section{Conclusion}

In this study, we have examined Turkish variation sets in child and child-directed speech longitudinally. Variation sets play a leading role in CDS for effective communication. It allows young children to process information gradually in rich and varied contexts. Variation sets in Turkish represent rich morpho-syntactic properties. Strategies for making the interaction more effective were also given particular interest. It is evidenced in the data that the nature of child and child-directed speech changes substantially over the time. These two speeches are in constant relationship with each other. The capabilities of a child -linguistically, cognitively and physicallyare the determining factors in the parents' orientation in interaction and language use. With the help of variation sets, the child broadens his knowledge on the systems and functions of language. S/he grasps the boundaries of words and structures in L1. As all words and structures are provided in contextual interaction, the child develops a growing awareness of how to use them.

This study confirms that as Turkish is a highly inflected language, children start using verb inflections before 2 years old (Aksu-Koc \& Slobin, 1985, Inci-Kavak, 2018, 2019). Furthermore, the data show that the selected child's use of verb grows steadily and quickly (from $16 \%$ to $44 \%$ ) between the ages of 20 and 22 months. However, the child's noun use does not change at the same level and it relatively remains steady at $20 \%$. It can be inferred that the child's verbal skills improve more than nominal ones during these months. When we compare the ratio of the child's and parent's verb and noun use, they go hand in hand. While the gap between their verb uses diminishes as the child grows, the gap between their noun uses remains at the same level with no apparent drop or rise.

The study evinces that Turkish child-directed speech provides us with the samples of rich variation sets in different forms. In this way, Turkish parents can effectively manage communication with their young children. As the child grows up, the 
interaction between the mother and child gets more accurate and expressive. The child, even at the very early stages of L1 acquisition, shows a tendency towards producing more diverse, effective and non-deviating, in other words, more natural and mother-like variation sets.

In the previous studies on language acquisition, the social and pragmatic dimension of the speech has been ignored or not given much importance (Küntay \& Slobin, 2002). We have to highlight that not only the structure of input but also its communicative functions should be studied in detail. However, the number of studies analysing variation sets in all languages including Turkish remains scarce. More studies should be done to analyse how parents and children use variation sets to make the interaction more effective and meaningful for each other. How some changes in word order and the morphological system of word such as substitutions, deletions, additions, segmentations and other minor differences occur during interaction and what reflections these alternations cause on conversational pragmatics need more attention from scholars. Therefore, more research is required to understand the (a)symmetry between the noun and verb use as in Altınkamıs, Kern and Sofu's study (2014). As a final word, whether the proportion of verb/noun use in CD/CDS and also the nature of the variation set changes in more structured activities need further research.

\section{The Research and Publication Ethics Statement}

Data were collected after getting the consent of the legal guardian of the participant. No ethical considerations were violated in this study.

\section{The Conflict of Interest Statement}

In line with the statement of Committee on Publication Ethics (COPE), we hereby declare that we had no conflicting interests regarding any parties of this study.

\section{References}

Aksu-Koç, A. (1998). The acquisition of aspect and modality: The case of past reference in Turkish. Cambridge, UK: Cambridge University Press.

Aksu-Koc, A. \& Slobin, D. I. (1985). The acquisition of Turkish. In Slobin, D. I., (Ed.) The crosslinguistic study of language acquisition. Vol. 1. The data. Hillsadle, NJ: Erlbaum.

Altınkamış, F., Kern, S., \& Sofu, H. (2014). When context matters more than language: Verb or noun in French and Turkish caregiver speech. First Language, 34(6), 537-550.

Barrett, M., Harris, M., \& Chasin, J. (1992). Early lexical development and maternal speech: A comparison of children's initial and subsequent uses of words. Journal of Child Language, 18, 21-40.

Bazeley, P. (2007). Qualitative data analysis with NVivo. London: Sage.

Brodsky, P., Waterfall, H. R., \& Edelman, S. (2007). Characterizing motherese: On the computational structure of child-directed language. In D.S. McNamara \& J. G. Trafton, (Eds.), Proceedings of the 29th cognitive science society conference (pp. 833-838). California: University of California Press. 
Broen, P. A. (1972). The verbal environment of the language-learning child. American speech and hearing association monographs, number 17, Washington, DC: American Speech and Hearing Association.

Che, E., Brooks, P. J., Alarcón, M.F., Yannaco, F.D., \& Donnelly, S. (2017). Assessing the impact of conversational overlap in content on child language growth. Journal of Child Language, 45(1), 72 - 96.

Chomsky, N., (1988). Language and problems of knowledge: The Managua lectures. Cambridge: The MIT Press.

Clark, E. V. (2009). First language acquisition (2nd ed.). Cambridge, England: Cambridge University Press.

Clark-Stewart, K. A. (1973). Interactions between mothers and their young children: Characteristics and consequences. Monographs of the Society for Research in Child Development 38 (Serial No. 153).

Cohen, L., Manion, L., \& Morrison, K. (2011). Research methods in education (7th ed.). London: Routledge/Falmer.

Creswell, J. W. (2012). Qualitative inquiry and research design: Choosing among five approaches (4 ${ }^{\text {th }}$ Edition). California: Sage.

Cross, T.G., (1976). Motherese: Its association with rate of syntactic acquisition in young children. In N. Waterson \& C. Snow, (Eds.), The development of communication: Social and pragmatic factors in language acquisition. New York: Wiley.

Dickinson, D., \& McCabe, A., (1991). The acquisition and development of language: A social interactionist account of language and literacy development. In J.F. Kavanagh, (Ed.) The language continuum: From infancy to literacy (pp. 1-40). Parkton, MD: York Press.

Fernald, A. (1976). The mother's speech to the newborn. Paper presented at the Max-Plank Institute for Psychiatry, Munich.

Fernald, A. (1989). Intonation and communicative intent in mothers' speech to infants: Is the melody the message?. Child development, 1497-1510.

Fernald, A., \& Mazzie, C. (1991). Prosody and focus in speech to infants mothers' speech to new-borns. Developmental Psychology, 27, 209-221.

Field, T., Woodson, R., Greenberg, R., Cohen, D., (1982). Discrimination and imitation of facial expressions by neonates. Science 218, 179-181.

Frank, S. L., Bod, R., \& Christiansen, M. H. (2012). How hierarchical is language use?. Proceedings of the Royal Society B: Biological Sciences, 279(1747), 4522-4531.

Gallaway, C., \& Richards, B.J. (1994). Input and interaction in language acquisition. Cambridge: Cambridge University Press.

Gleitman, L., Newport, E., \& Gleitman, H. (1984). The current status of the motherese hypothesis. Journal of the Child Language, 11(1), 43-79.

Göksel, A., \& Kerslake, C. (2005). Turkish. London and New York: Routledge.

Grigonytè, Gintarè, \&Björkenstam, Kristina N. (2016). Language-independent exploration of repetition and variation in longitudinal child-directed speech: a tool and resources. In Proceedings of the Joint Workshop on NLP for Computer Assisted Language Learning and NLP for Language Acquisition at SLTC, Umeå, 16th November 2016 (pp. 41- 50). Linköping University: Electronic Press.

Hatch, J. A. (2002). Doing qualitative research in education settings. New York: State University of New York Press.

Hoff-Ginsberg, E. (1986). Function and structure in maternal speech: Their relation to the child's development of syntax. Developmental Psychology, 22, 155-63. 
Hoff-Ginsberg, E. (1990). Maternal speech and the child's development of syntax: A further look. Journal of Child Language, 17, 85-99.

İnci-Kavak, V. (2018). The development of forms of negation in the acquisition of Turkish. Journal of Language and Linguistic Studies, 14(4), 93-110.

Inci-Kavak, V. (2019). The acquisition and use of negation in the early child language. Journal of Language and Linguistic Studies, 15(2), 587-604.

Janesick, V. J. (2004). Stretching exercises for qualitative researchers (2 ${ }^{\text {nd }}$ Edition). Thousand Oaks, CA: Sage.

Jusczyk, P. W., Hirsh-Pasek, K., Kemler Nelson, D. G., Kennedy, L., Woodward, A., \& Piwoz, J. (1992). Perception of acoustic correlates of major phrasal units by young infants. Cognitive Psychology, 24, 252-293.

Kaye, K. (1980). Why we don't talk 'baby talk' to babies. Journal of Child Language, 7(03), 489-507. doi:10.1017/S0305000900002804.

Küntay, A., \& Slobin, D. I. (1999). The acquisition of Turkish as a native language. A research review. Turkic Languages, 3, 151-188.

Küntay, A., \& Slobin, D. I. (1995). Nouns and verbs in Turkish child directed speech. In D. MacLaughlin, \& S. McEwen (Eds.), Proceedings of the 19th Annual Boston University Conference on Language Development 1 (pp. 323-334). Somerville, MA: Cascadilla Press.

Küntay, A., \& Slobin, D. I. (1996). Listening to a Turkish mother: Some puzzles for acquisition. Social interaction, social context, and language: Essays in honor of Susan Ervin-Tripp, 265286.

Küntay, A., \& Slobin, D.I. (2002). Putting interaction back into child language: Examples from Turkish. Psychology of Language and Communication, 6(1), 5-14.

Landis, J. R., \& Koch, G. G. (1977). An application of hierarchical kappa-type statistics in the assessment of majority agreement among multiple observers. Biometrics, 363-374.

Lederer, A., \& Kelly, M. H. (1991). Prosodic correlates to the adjunct/complement distinction in motherese. Papers and Reports on Child Language Development, 30, 55-63.

Lincoln, Y.S., \& Guba, E. G. (1985). Naturalistic inquiry. Newbury Park, CA: Sage.

Matychuk, P. (2005). The role of child-directed speech in language acquisition: A case study. Language sciences, 27 (3), 301-379.

Merriam, S. B. (1998). Qualitative research and case study applications in education. San Francisco: Jossey-Bass Publishers.

Morgan, J. L. (1986). From simple input to complex grammar. Cambridge: MIT Press.

Ninio, A. (1992). The relation of children's single word utterances to single word utterances in the input. Journal of Child Language, 19, 87-110.

Onnis, L., Waterfall, H.R., \& Edelman, S. (2008). Learn locally, act globally: Learning language from variation set cues. Cognition, 109, 423-430.

Papoušek, M., \& Papoušek, H. (1981). Musical elements in the infant's vocalization: Their significance for communication, cognition, and creativity. Advances in infancy research.

Papoušek, H., \& Papoušek, M. (1987). Intuitive parenting: A dialectic counterpart to the infant's integrative competence. In J. D. Osofsky (Ed.), Wiley series on personality processes. Handbook of infant development (pp. 669-720). John Wiley \& Sons.

Pine, J., Lieven, E., \& Rowland, C. (1997). Stylistic variation at the "single-word" stage: Relations between maternal speech characteristics and children's vocabulary composition and usage. Child Development 68, 807-19.

Piper, T. (1998). Language and learning: The home and school years. Merrill: Pearson.

Richards, L., \& Morse, J. M. (2007). Users guide for qualitative methods (2 ${ }^{\text {nd }}$ Ed.). Thousand Oaks, CA: Sage.

Saldana, J. (2015). The coding manual for qualitative researchers. California: Sage. 
Slobin, D. I. (1982). Universal and particular in the acquisition of language. In E. Wanner \& L. R. Gleitman (Eds.), Language acquisition: The state of the art, (pp. 128-72). Cambridge: Cambridge University Press.

Shneidman, L. A., \& Goldin-Meadow, S. (2012). Language input and acquisition in a Mayan village: How important is directed speech?. Developmental science, 15(5), 659-673.

Snow, C.E. (1972). Mothers' speech to children learning language. Child Development (43), $549-565$.

Slobin, D. I., Küntay, A., \& Hoiting, N. (2001, April). Parental variations on a theme as a guide to language form and use. Paper presented to the Biennial Meeting of the Society for Research in Child Development, Minneapolis, MN.

Snow, C.E., (1984). Parent-child interaction and the development of communicative ability. In I.R.L. Scheifelbusch, \& J. Pickar (Eds.), The acquisition of communicative competence (pp. 69-107). Baltimore, MD, University Park Press.

Snow, C.E., (1995). Issues in the study of input: Finetuning, universality, individual and developmental differences, and necessary causes. In P. Fletcher \& B. MacWhinney (Eds.), The handbook of child language: The spoken language, early speech development. (pp. 180193). Cambridge, MA: Blackwell.

Snow, C., \& Ferguson, C. (1977). Talking to children: Language input and acquisition. Cambridge: Cambridge University Press.

Sofu, H. ,Türkay, F. (2004). Input Frequency Effects of Child-Directed Speech in Terms of Noun-Verb Dominance. Presented Conference on (In)determinismus in der Sprache on February 23-25, 2005. University of Cologne.

Spall, S. (1998). Peer debriefing in qualitative research: Emerging operational models. Qualitative Inquiry, 4(2), 280-292.

Spillett, M. A. (2003). Peer debriefing: Who, what, when, why, how. Academic Exchange Quarterly, 7(3), 36-40.

Stern, D., Beebe, B., Jaffe, J., Bennet, S., (1977). The infant's stimulus world during social interaction: A study of caregiver behaviors with particular reference to repetition and timing. In H. Schaffer (Eds.), Studies in mother-infant interaction (pp. 177-202). New York: Academic Press.

Shira, T. A. L., \& Arnon, I. (2018). SES effects on the use of variation sets in child-directed speech. Journal of child language, 45(6), 1423-1438.

Tardif, T., Shatz, M. \&Naigles, L. (1997). Caregiver speech and children's use of nouns versus verbs: A comparison of English, Italian, and Mandarin. Journal of Child Language 24, 535-565.

Waterfall, H. R. (2006). A little change is a good thing: Feature theory, language acquisition and variation sets. Unpublished doctoral dissertation, University of Chicago.

Wells, C.G., (1980). Adjustments in adult-child conversation: some effects of interaction. In: H. Giles, W.P Robinson, \& R.M. Smith, (Eds.), Language: Social psychological perspectives (pp. 41-48). Oxford, Pergammon Press.

Wirén, Mats, Björkenstam, Kristina, N., Grigonytè, G., \& Cortes, E. E. (2016). Longitudinal studies of variation sets in child-directed speech. In The 54th Annual Meeting of the Association for Computational Linguistics, Berlin, Germany, August 11, 2016 (pp. 44-52). Association for Computational Linguistics.

\section{Copyrights}

Copyright for this article is retained by the author(s), with first publication rights granted to the Journal.

This is an open-access article distributed under the terms and conditions of the Creative Commons Attribution license (CC BY-NC-ND) (http://creativecommons.org/licenses/by-nc-nd/4.0/). 